\title{
Nanomaterials as Electrochemical Labels for Biosensors
}

\author{
Alba Iglesias-Mayor and Agustín Costa-García* \\ Department of Physical and Analytical Chemistry, University of Oviedo, Spain
}

Submission: June 13, 2017; Published: June 22, 2017

"Corresponding author: Agustín Costa-García, Nanobioanalysis Group, Department of Physical and Analytical Chemistry, University of Oviedo, 8 Julián Clavería St. Oviedo 33006, Spain, Tel: +34985103488; Email: costa@uniovi.es

Abstract

In recent years, many efforts have been carried out to develop alternatives to the use of enzymes as electroactive labels. Nanomaterials have been used for many applications in the development of electrochemical biosensors and currently the use of modified nanoparticles is booming in this research area. This mini review is focused in the use of electroactive metallic nanoparticles modified with a biologic element for electrochemical biosensing.

Keywords: Electrochemistry; Biosensors; Nanomaterials; Labels; Metallic-nanoprobes

\section{Mini Review}

Nanotechnology has played a key role in the development of biosensors over the past decade. Due to their effects (small size, surface and interface and quantum size), nanomaterials can improve analytical characteristics of biosensors, such as stability, repeatability, and sensitivity. Generally, electrochemical biosensors based on nanomaterials canamplify the sensitivity by enabling a greater loading of the sensing surface with bioreceptors, and the use of nanomaterials also helps to increase charge and electron transfer [1-3].

The use of nanomaterials in biosensing technology is highly influenced by theirproperties, which depends on the synthesis, and therefore its quality, and on subsequent modifications, both biological or chemical. Recent trends have shown the conjugation of nanomaterials with biomolecules or target analytes through a wide range of interactions, such as physical adsorption, covalent attachment, and electrostatic interaction [4]. Nanomaterials can be functionalized with polymers or biomolecules to achieve higher biocompatibility, making possible the integration of these materials in biosensors. Nevertheless, any coating must be attached to the nanomaterials before their use [5]. Bioassays are based on the affinity interaction between the analyte and the labelled bioreceptor. This interaction is designed to produce a measurable signal, detected with a proper transducer.

Over the last years, nanomaterials have attracted much attention as labels in the development of affinity electrochemical biosensors. A wide range of nanomaterials is used, ranging from noble metal nanoparticles (NPs), inorganic nanoparticlesor carbon nanomaterials to quantum dots (QDs).

An interesting possibility is the modification of the nanomaterials with biological elements, such as avidin or biotin and basing the performance of the biosensor in the biotin-avidin specific recognition. In our group, some experiments of this type have been developed using quantum dots and metal-modified titanium phosphate nanoparticles (MTiPNPs) coated with biotin or streptavidin [6-8]. QDs and MTiPNPs can be used as detection label in electrochemical voltammetric biosensors thanks to its metallic electroactive species. After taking place the affinity interaction, detection is carried out by measuring the cations generated from the corresponding metallic nanolabels [9]. An overview of the process is shown in Figure 1.

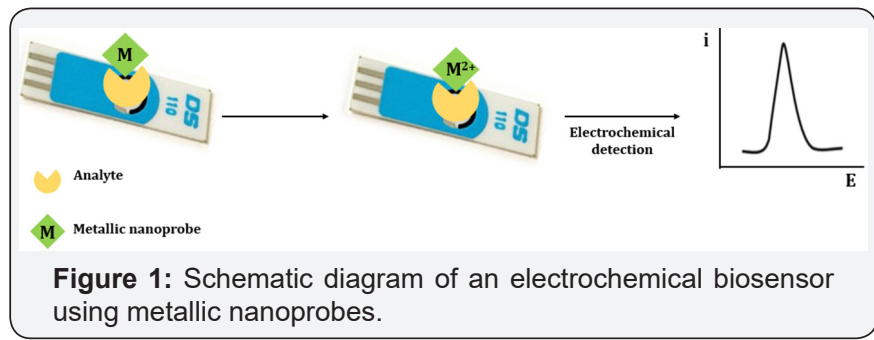

\section{Acknowledgement}

This work has been supported by the CTQ2014-58826Rproject from the Spanish Ministry of Economy and Competitiveness (MINECO). Alba Iglesias-Mayor thanks the 


\section{Current Trends in Biomedical Engineering \& Biosciencess}

Spanish Ministry of Education, Culture and Sports (MECD) for the award of a FPU Grant (FPU2014/04686).

\section{References}

1. Niina J Ronkainen, Stanley L Okon (2014) Nanomaterial-based electrochemical immunosensors for clinically significant biomarkers. Materials 7(6): 4669-4709.

2. Merkoçi A (2010) Nanoparticles-based strategies for DNA, protein and cell sensors. Biosens. Bioelectron 26(4): 1164-1177.

3. Zhang Y, Wei Q (2016) The role of nanomaterials in electroanalytical biosensors: A mini review. J Electroanal Chem 781: 401-409.

4. Valera E, Hernández-Albors A, Pilar MM (2016) Electrochemical coding strategies using metallic nanoprobes for biosensing applications. TrAC Trends Anal Chem 79: 9-22.

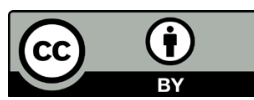

This work is licensed under Creative Commons Attribution 4.0 License

DOI:10.19080/CTBEB.2017.05.555664
5. Hayat A, GaëlleCatanante, Jean LM (2014) Current Trends in Nanomaterial-Based Amperometric Biosensors. Sensors 14(12): 23439-23461.

6. Yerga DM (2016) Aplicaciones electroanalíticas de Quantum Dots y Nanopartículas de Fosfato de Titanio. PhD Thesis, University of Oviedo.

7. Martín-Yerga D, Gonz lez-García MB, Costa-García A (2013) Biosensor array basedonthe in situ detection of quantum dots as electrochemicallabel. Sens Actuators B: Chemical 182: 184-189.

8. Martín-Yerga D, González-García MB, Costa-García A (2014) Electrochemical immunosensor for anti-tissue transglutaminase antibodies based on the in situ detection of quantum dots. Talanta 130 598-602.

9. Christos K, Anastasios E (2017) Emerging trends in biosensing using stripping voltammetric detection of metal-containingnanolabels- A review. Anal Chim Acta 962: 12-32.

\section{Your next submission with Juniper Publishers will reach you the below assets}

- Quality Editorial service

- Swift Peer Review

- Reprints availability

- E-prints Service

- Manuscript Podcast for convenient understanding

- Global attainment for your research

- Manuscript accessibility in different formats (Pdf, E-pub, Full Text, Audio)

- Unceasing customer service

Track the below URL for one-step submission https://juniperpublishers.com/online-submission.php 